\title{
Island bees: do wood nesting bees have better island dispersal abilities?
}

\author{
Nikolaj Rauff Poulsen, Claus Rasmussen \\ Department of Bioscience, Aarhus University, Ole Worms Allé 1, 8000, Aarhus C, Denmark
}

Received 20 November 2019 - Revised 4 May 2020 - Accepted 28 May 2020

\begin{abstract}
For bees to reach isolated islands, they need to be able to cross large water barriers. However, functional traits such as nesting behavior, flight range, and body size can limit their dispersal. In this study, the bee faunas of seven different islands or island groups (Anholt, Canary Islands, Fiji Islands, Hawaiian Islands, Madeira, Malta, and Sri Lanka) were analyzed by comparing them to the mainland bee fauna. Nesting strategy and body size for each species were recorded. The relative distribution of traits among the island species were then compared to traits of the mainland species. We found that among islands located furthest from mainland, the proportion of wood nesting bees are higher than for those located closer to mainland, suggesting that wood nesting bees are more capable of island dispersal, most likely due to the associated rafting ability or the ease of being passively transported over water. The body size among the immigrated island species were shown to be commonly of moderate size, while a majority of mainland species were of small size, indicating that moderate sized bees - with longer flight range - were the more likely island migrators. The methods used could be useful for future studies of ecological influences on body size, as well as how other biological traits are adapted for migrant conditions, potentially serving as predictors in regards to climate change, dispersal ability, and control of invasive species.
\end{abstract}

\section{island biogeography / insect dispersal / rafting / Hymenoptera / Apidae}

\section{INTRODUCTION}

Bees (Hymenoptera: Anthophila) are a large and diverse clade of insects, consisting of approximately 20,000 different species (Ascher and Pickering, 2019). Within the clade, a wide diversity can be found in terms of morphological and ecological strategies for reproduction and foraging (Michener et al., 1994; Michener, 2007). Bees usually nest in ground burrows or cavities in sticks, stems, and branches (Michener, 1964;

Electronic supplementary material The online version of this article (https://doi.org/10.1007/s13592-020-00778-x) contains supplementary material, which is available to authorized users.

Corresponding author: C. Rasmussen, claus.rasmussen@bios.au.dk

Manuscript editor: James Nieh
Cane and Neff, 2011), with some bees having more specialized nesting strategies, e.g., nesting on cliffs (Roubik et al., 1985), in snail shells (Müller et al., 2018), or in a diversity of selfmade aerial nests (Dressler, 1982; Wcislo et al., 2012; Rasmussen et al., 2015). In terms of sociality, the majority of bee species, $>85 \%$, does not live in larger groups like the honey bee (Apis mellifera), but live solitarily (Batra, 1984; Danforth et al., 2019). The smallest known bees are about $2 \mathrm{~mm}$ long (Michener, 2007), while some of the largest known bees include Wallace's giant bee (Megachile pluto ), with a body length of approximately $40 \mathrm{~mm}$ (Messer, 1984; Main, 2019). This diversity among the bees comes from a long evolutionary timeframe, which is thought to have begun already during the Early Cretaceous $(140$ to $110 \mathrm{Ma})$, with the bees arising within apoid wasps in the arid interior of west 
Gondwanaland (Africa, South America) (Michener, 1979), or most likely in modern Africa (Danforth et al., 2006; Danforth and Poinar, 2011). Their origin here coincides with the diversification of flowering plants (Angiosperms) (Cardinal and Danforth, 2013). This synchrony of the timing in the origin of the bees and angiosperm diversification, represent one of the most successful coevolutionary partnerships (Danforth et al., 2013), with bees dependent on food from angiosperm flowers, and many angiosperms dependent on bees for pollination (Michener, 1979). Because of this partnership, bees are considered among the most important pollinators of flowering plants - of which $78 \%$ in temperate communities and $94 \%$ in tropical communities depend on animal pollinators (Ollerton et al., 2011).

Such plant-pollinator dependency can also provide a limitation for angiosperms that disperse to new islands. Particularly, self-incompatible angiosperms species are at a disadvantage when colonizing islands, especially after long dispersal, because self-incompatible species require a minimum of two individuals in addition to an animal vector, to become established (Inoue et al., 1996). For bees to reach isolated or oceanic islands and become potential pollinators of angiosperms present therein, they need first to cross large water barriers. While natural dispersal capacity is little known for bees, some data exists about foraging range, although this is necessarily shorter than maximum flight range. For solitary bees, the maximum recorded foraging distance is $1400 \mathrm{~m}$ for the larger species, with the maximum foraging range decreasing for smaller species with some only foraging between 100 and $300 \mathrm{~m}$ away from the nest (Zurbuchen et al., 2010). An exception to this are some orchid bees (Apidae: Euglossini: Eulaema) that have been observed returning to their nest as far away as $23 \mathrm{~km}$ or more (Janzen, 1971; Wikelski et al., 2010). Even with a potential flight distance of $23 \mathrm{~km}$ for the strongest fliers among bees, bees would only be able to actively make it to a very narrow selection of islands that are not well isolated geographically (Holzapfel and Harrell, 1968; Ashmole and Ashmole, 1988; Peck, 1994). Yet, bees today are found on all continents, except Antarctica, including remote islands with harsh winter conditions (Michener, 2007; Williams et al., 2019). In order for bees to have naturally dispersed across most of the continents and major continental islands, dispersal must have taken place during a period when the continents were still adjacent, and most likely only separated by narrow water straits during the end of Cretaceous and beginning of Eocene (Michener 1979). For most bees, dispersal has presumably been slow across the continents and to the nearby landmasses, or by transport on moving continents (Michener, 1979). The bee faunas of the Antilles and of central Indonesia show that scattered islands between continents can serve as stepping stones between the continents (Michener, 1979), allowing island hopping/jump dispersal (Whittaker et al., 2007). Importantly, some island groups like the Canary and Hawaiian Islands had not formed during the Cretaceous, and both island groups (Gillespie and Clague, 2009), especially the Hawaiian Islands, are located far out in the ocean, with no possibility for jump dispersal. For Hylaeus (Nesoprosopis) to have arrived to Hawaii during a single rare event, possible from Japan, some other dispersal mechanism would be necessary (Daly and Magnacca 2003). Wind dispersal to islands of the smaller bees have been suggested as a possible dispersal mechanism, but most bees prefer to stay in the nest during storms, only adventuring out to fly in good weather, thus severely limiting the number of individuals available for accidental dispersal during storms (Michener, 1979). Yet, storms and violent weather might still play a role in the island dispersal of bees. Bees nesting protected inside sticks, branches, or stems could be rafted or blown in severe storms, potentially moving bee nests to an isolated island where angiosperm pollen and nectar are available for food, providing opportunities for the establishment of a bee fauna. Bee species are also during the last 200 years recorded as exotic outside their native range, in particular around commodity entry points, and are evidently able to survive accidental or facilitated longdistance transport on trans-oceanic cargoes (Cane, 2003; Sheffield et al., 2011; Jensen and Madsen, 2018; Rasmussen et al., 2020). Such human-mediated events may very well be frequent and important. 
In this study, we test the hypothesis by the late Charles Michener, world bee authority, regarding bees on chiefly oceanic islands: Bees of all sizes that primarily nest in wood, stems, or twigs are most likely to make major dispersal steps across large water barriers, while moderate and largesized ground nesting bees are less likely to do so (Michener, 1979). We addressed this by compiling species lists for each of the selected islands, including species-specific biological traits. We then compare these biological traits with the selection of species that are non-endemic island species, with those traits found for bees globally, or, outside the respective island. For each of the studied islands, we will also look at the species composition, to test if the bee fauna is identical to that of the closest mainland.

\section{MATERIAL AND METHODS}

Islands The selected islands or island groups (Anholt, Canary Islands, Fiji Islands, Hawaiian Islands, Madeira, Malta, and Sri Lanka) vary in area size, topology, distance to the closest mainland, and number of observed bee species (Table I). The islands were selected based on the resident bee fauna, according to our knowledge, being well documented in the literature and containing putatively native species found both on nearest mainland and on the island.

Species lists For each island, a list of present and fully identified species was compiled, based on the available literature. Subspecies were not recognized and instead treated as the nominal species. All records were cross-referenced with the online taxonomic resources by Ascher \& Pickering (2019) for confirmation of the occurrence record, avoidance of pseudo-replicates, and standardization of nomenclature used. The literature references used, including the number of observed bee species for each island, are listed in Table II (species lists can be found in Appendix A). For each of the islands' species, the global distribution was determined from the Discover Life (Ascher and Pickering 2019) and iNaturalist databases (iNaturalist.org 2019) in order to categorize species as either (1) endemic to the island studied or (2) having migrated there with presence on both the island and elsewhere. This was necessary as only traceable and immigrated species were of interest. Although of importance, we were not able to differentiate between species that have been brought across oceans aided by humans and those that presumably have arrived without human assistance. Such information is scattered and often non-existent or indirect (see for example Rasmussen et al., 2012), with the exception of, e.g., some honey bee species (Winston et al., 1981; Sammataro and Avitabile, 1998). Species observed from both islands and mainland were recorded as a confirmed island immigrant and used for further analysis. Species only recorded from the islands were noted as endemic and excluded from further analysis as their origin and migration route could not be traced from our available data.

Species data collection Collection of body size and nesting strategy data for all immigrated island species was extrapolated from available data for the subgenus or genus, as complete biological data at the species level is mostly lacking, and because supraspecific data can be used as a proxy for biology at the species level (Michener 2007). Data was recorded from Michener (2007) and included body size range and nesting strategy. Data collection for body size range measurements included a minimum and maximum body length in millimeters for lowest taxonomic level (genus or subgenus) as listed by Michener (2007). Within the genera Andrena (Andrenidae) and Bombus (Apidae), body range data were incomplete for the subgenera. To compensate for this, an unpublished dataset containing body length measurement of all Danish bee species was used. If available, the measured size of the reproductive females was used; otherwise, males were used to represent the size range for the subgenus. If no individuals were available, size data for the genus was used. Each immigrated island species was recorded as either a ground nesting or wood nesting species. Species with the plasticity to use both strategies were treated and analyzed as both ground and wood nesting. Ground nesting refers to a taxon that is nesting below ground surface in cavities, burrows, or similar. Wood nesting refers to a taxon that is nesting inside pre-existing or 
Table I. Each of the studied islands, with island type, area and distance to closest mainland noted. Island type is noted as $\mathrm{CI}=$ Continental island(s) or OI = Oceanic island(s), and follows the definition by Whitaker and others (2007)

\begin{tabular}{lccr}
\hline Location & Island type & Area $\left(\mathrm{km}^{2}\right)$ & Current distance $(\mathrm{km})$ from nearest mainland \\
\hline Anholt & CI & 22 & 45 (Denmark) \\
Canary Islands & OI & 7273 & 108 (Northwestern Africa) \\
Fiji Islands & OI & 18,275 & 2400 (Australia) \\
Hawaiian Islands & OI & 28,311 & 3650 (USA) \\
Malta & CI & 314 & 82 (Italy) \\
Madeira & OI & 792 & 630 (Morocco) \\
Sri Lanka & CI & 65,610 & 27 (India) \\
\hline
\end{tabular}

self-excavated tree stems or sticks. Species using other and unusual nesting strategies were excluded from further analysis; the same was done for brood parasites that take over the nests of nestbuilding species.

Nesting strategy analysis For each island, the number of immigrated species nesting in either the ground or in wood were counted, and the total percentage distribution of these nesting strategies were calculated based on the total amount of included immigrated species on the island. Because some species were categorized as both ground and wood nesting, the calculated percentage distribution was defined as the highest potential percentage of immigrated ground/wood nesting species for the island. In order to compare the

Table II. Number of species observed for each island, including references. Asterisks $(*)$ indicate that data from the Discover Life (Ascher and Pickering 2019) species list were included

\begin{tabular}{|c|c|c|c|c|}
\hline Species inventories for islands & Location & $\begin{array}{r}\text { Total \# of } \\
\text { species }\end{array}$ & $\begin{array}{c}\text { \# of non-endemic } \\
\text { wood nesting spe- } \\
\text { cies }\end{array}$ & $\begin{array}{c}\text { \# of non-endemic } \\
\text { ground nesting spe- } \\
\text { cies }\end{array}$ \\
\hline $\begin{array}{l}\text { Madsen et al., 2015; } \\
\text { Rasmussen et al., } 2016\end{array}$ & Anholt & 146 & 33 & 94 \\
\hline $\begin{array}{l}\text { Hohmann et al., 1993; } \\
\text { Fellendorf et al., 1999; } \\
\text { Smit, 2007; Kratochwil } \\
\text { and Schwabe, 2018,* }\end{array}$ & Canary Islands & 122 & 15 & 57 \\
\hline $\begin{array}{l}\text { Davies et al., 2013; } \\
\text { Groom et al., 2013; } \\
\text { da Silva et al., 2016,* }\end{array}$ & Fiji Islands & 15 & 8 & 5 \\
\hline $\begin{array}{l}\text { Daly and Magnacca, 2003; } \\
\text { Snelling, 2003; } \\
\text { Rasmussen et al., 2012; } \\
\text { Vargas et al., } 2015\end{array}$ & $\begin{array}{l}\text { Hawaiian } \\
\text { Islands }\end{array}$ & 83 & 16 & 9 \\
\hline Balzan et al., 2016,* & Malta & 110 & 33 & 65 \\
\hline $\begin{array}{l}\text { Hohmann et al. 1993; } \\
\text { Fellendorf et al., 1999; } \\
\text { Kratochwil and Schwabe 2018,* }\end{array}$ & Madeira & 21 & 5 & 9 \\
\hline $\begin{array}{l}\text { Wijesekara, 2001; Inoka et al., } \\
2008, *\end{array}$ & Sri Lanka & 141 & 28 & 52 \\
\hline
\end{tabular}


percentage distribution for each of the islands, the same distributions were calculated globally across all taxa in Michener (2007). Number of species for each subgenera and genera were taken into account, to provide as close as possible a species-level estimation for the distribution of each nesting strategy. The distribution of island nesting strategies were then compared to the distribution of nesting strategies globally, allowing for the calculation of an immigrated island species deviation in the distribution for ground and wood nesting species. Deviations for each island and nesting strategy were plotted against the islands' distance to the nearest mainland.

Body size analysis In order to compare body length of the immigrated island species to the species on the mainland, a mean size was calculated based on data provided by Michener (2007). Datasets of body sizes were thereafter individually divided into five predefined size categories, based on the categories interpreted from Michener et al. (1994): we established from here that "Minute" includes bees with a mean body size of $<5 \mathrm{~mm}$; "Small" are 5-10 mm; "Moderate" are 10-17 $\mathrm{mm}$; "Large" are 17-23 mm; "Very large" are > $23 \mathrm{~mm}$. The number of species for each of the size categories for both the immigrated island species, and the total species list were plotted individually as histograms, along with the percentage distribution among the size categories.

Statistical analysis Statistical analyses on nesting strategy, body size, and social behavior were completed utilizing RStudio software version 1.2.1335 (Boston, MA, http://www.rstudio.org/). The correlation between the nesting strategies and the distance to nearest mainland was tested in scatterplots via linear regression analyses, with a forced intercept at origin $(0,0)$. The forced intercept is used because the deviation at $0 \mathrm{~km}$ must equal $0 \%$. The categorical distribution of the mean sizes for the immigrated species was tested via a chi-squared-test, comparing them to the categorical distribution of the total species list. For this analysis, the percentage values for the matching categories were compared.

\section{RESULTS}

Nesting strategy The mainland distribution of the two different nesting strategies demonstrated that $64.18 \%$ of all species use a ground nesting strategy, while $32.41 \%$ are able to nest in wood. Deviation from the ground nesting strategy among the immigrated island species shows via linear regression analysis that $75.37 \%$ of the variance in the deviation $\left(R^{2}\right)$ can be explained by the independent variable (i.e., distance to the closest mainland) (Figure 1). The regression model specifically predicts that the percentage of ground nesting species would decrease; the further from the mainland the island is located ( $p$ value $=$ 0.0032 ). For the ground nesting strategy, Hawaii has the largest deviation at $-19.18 \%$ which correlates with the regression model, as Hawaii is also the island group located furthest from any mainland. Evidently, the endemic Hawaiian bee fauna is also the result of a single dispersal event followed by diversification (Magnacca and Danforth, 2006). The same can be said for the second closest island, Anholt, with the lowest deviation at $0.20 \%$. However, the deviation from Sri Lanka at $-11.12 \%$ appear to be lower than what the model predicts, considering that Sri Lanka is the island located closest to mainland. The regression model for the deviation of wood species showed that $86.46 \%$ of the variance $\left(R^{2}\right)$ for this type of nesting strategy can be explained via a linear model (Figure 2). The model predicts that the percentage of wood living species would increase, as the islands are moved further from the mainland $(p$ value $=0.0005)$.

Body size Dividing the total number of species and number of immigrated species into five different size categories shows a significant difference between the two distributions ( $p$ value $=$ $0.0021)$. A larger proportion of the immigrated island species were of moderate size (10-17 $\mathrm{mm})$, while a larger proportion of the mainland species were of the small $(<5 \mathrm{~mm})$ or large size (17-23 mm) (Figure 3). 


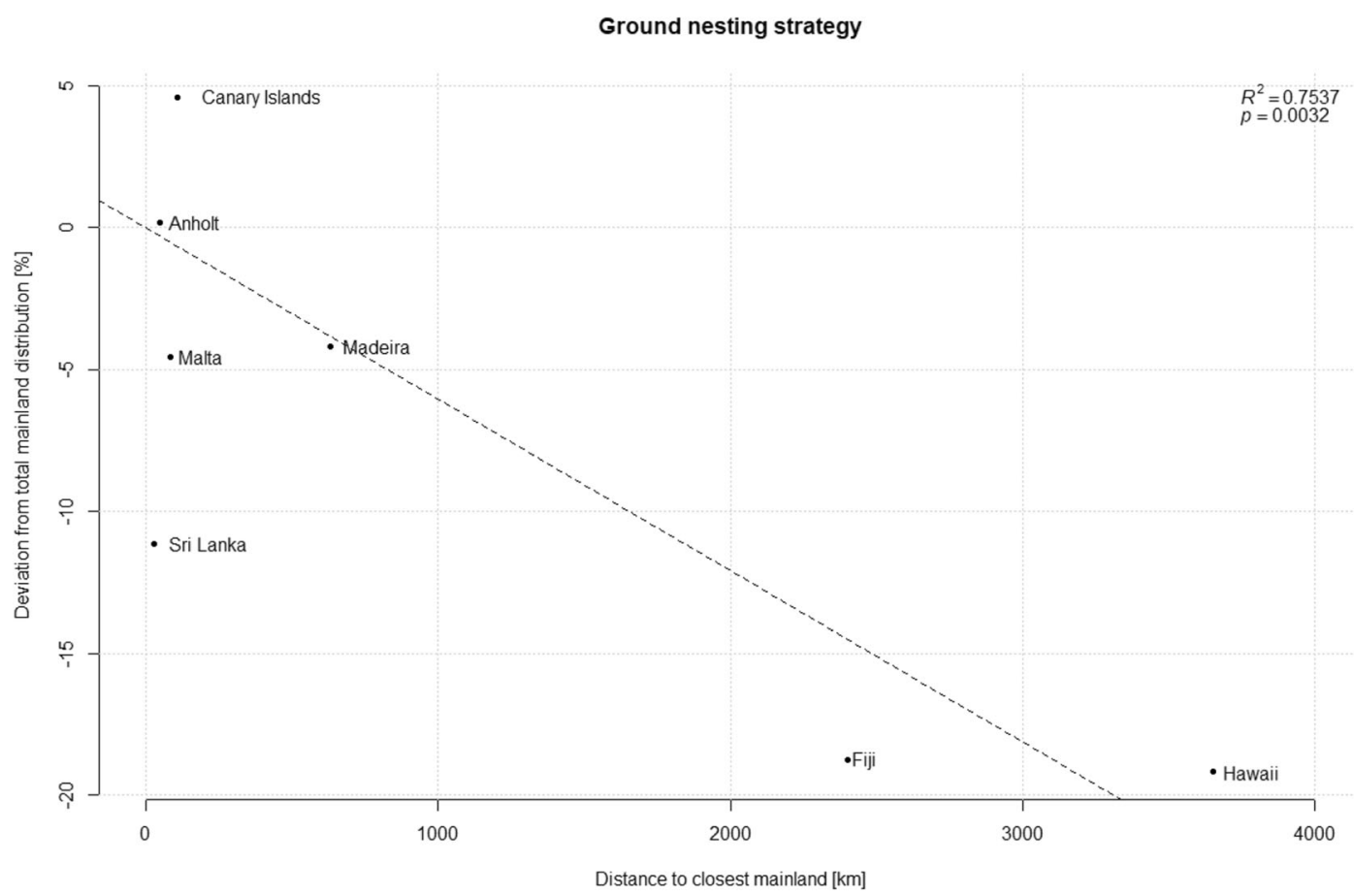

Figure 1. Deviation (\%) of the distribution of ground nesting species immigrated to each island, as compared to the global distribution of ground nesting strategy. Deviation is plotted against the distance to each island's closest mainland $(\mathrm{km})$. The total distribution of the ground nesting strategy was $64.18 \%$. The line represents the result of the linear regression analysis, with the $R^{2}$ value displayed.

\section{DISCUSSION}

The Theory of Island Biogeography by MacArthur and Wilson (1967) formulates in one of the most influential and successful theories in ecology, that the number of species in an island is determined by the size of the island and its distance from the mainland. The further away the island the fewer species. MacArthur and Wilson also emphasized the role of ecology in determining the species diversity for islands. When it comes to bees, it has been hypothesized that wood nesting bees have a greater chance of reaching oceanic islands due to the associated rafting ability or the ease of being passively transported over water, than ground nesting bees (Michener, 1979). We here fully support and quantify this, as the further away from the mainland an island is located, the higher is the proportion of immigrated island species that nest in wood
(Figure 2). The positive correlation found also supports that the larger the water barrier is, the larger the proportion of wood nesting species would be on the island. The opposite seems to be true for the ground nesting species, where the further from the mainland an island is, the further the negative deviation is for the proportion of ground nesting species (Figure 1). Michener (1979) also speculated that smaller "minute" adult bees were easily carried by the wind out to the islands. In contrast, we found that the body size of the immigrated island species showed a tendency to be larger than those found on mainland, with island species being dominantly moderate $(10-17 \mathrm{~mm})$ in size, while mainland species generally were smaller (Figure 3). The larger proportion of moderate sized bees on the islands shows that the chance of minute bees being carried to islands by wind is relatively low, or at least, that their survival and establishment, is lower 


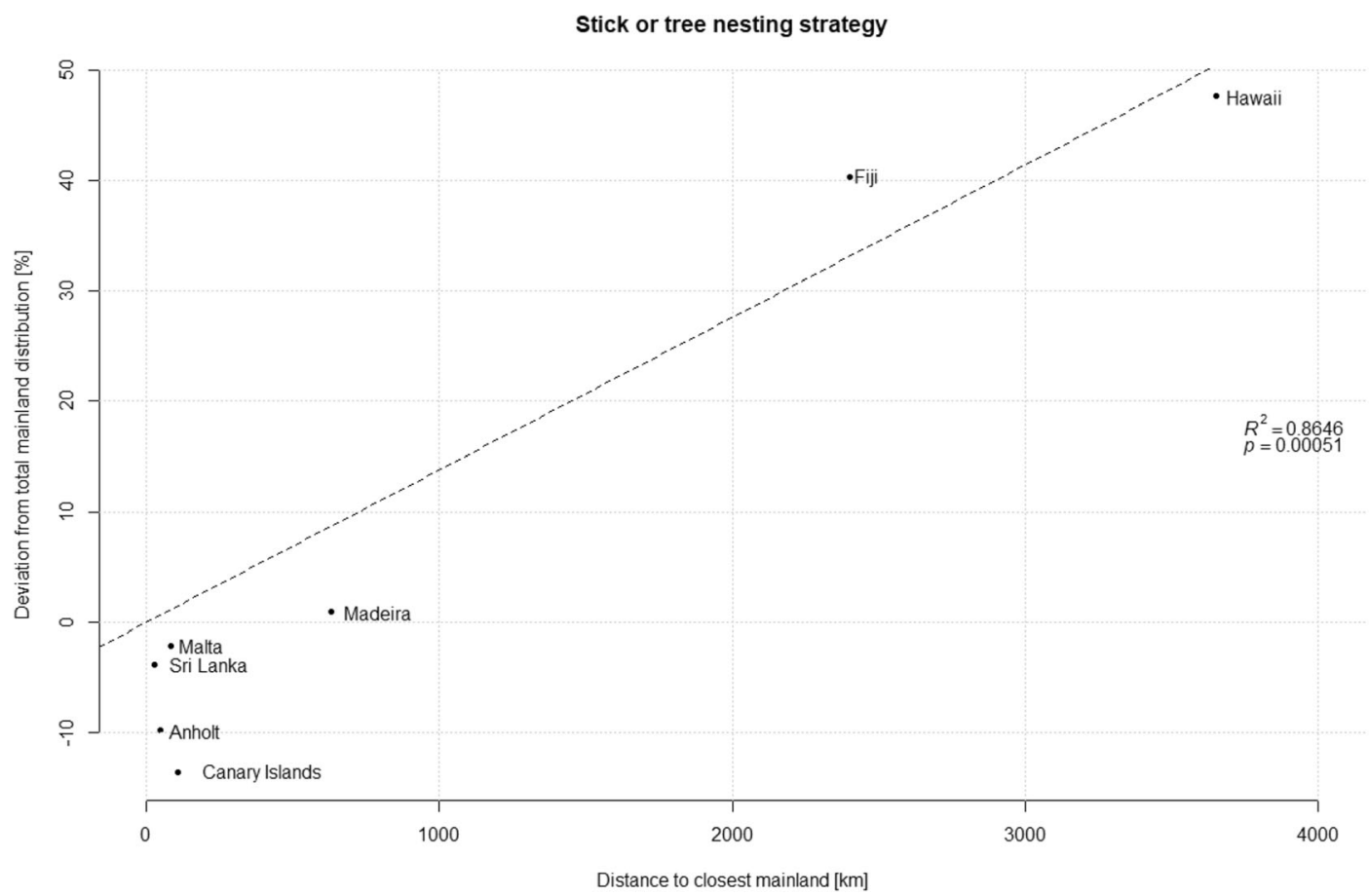

Figure 2. Deviation (\%) of the distribution of wood (stick or tree) nesting immigrated species of each island compared to the total distribution of this nesting strategy and plotted against the distance to each island's closest mainland $(\mathrm{km})$. The total distribution of the wood nesting strategy was $32.41 \%$. The line represents the result of the linear regression analysis, with the $R^{2}$ value displayed.

than moderate sized bees. Although not tested, moderate sized bees that are wood nesting, there may also be a higher proportion of compared to ground nesting. The lower than

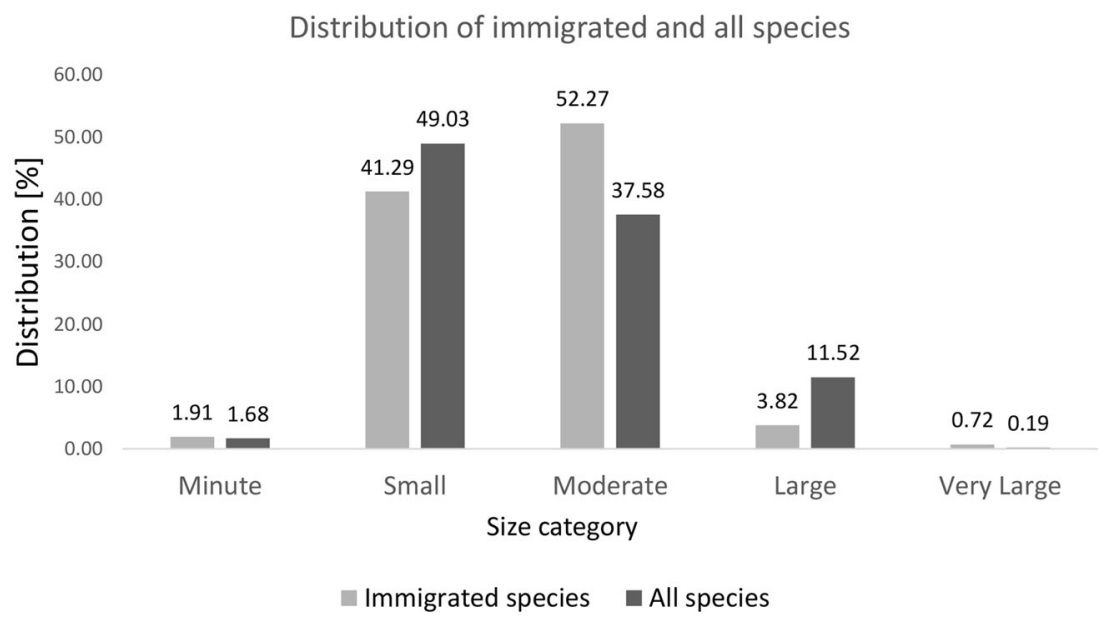

Figure 3. Percentage distributions among five size categories (minute, small, moderate, large, very large) for total number of species (black) and only the immigrated island species (gray). There are relatively more moderate sized species on islands, than anywhere else, and relatively fewer small or large sized species on islands. 
expected model deviation for Sri Lanka can possible be explained by the environment. Ground nesting bees are most diverse in arid environments while wood and cavity nesters are relatively more common in wet environments (Michener, 2007). Sri Lanka and southern India with the mainly wet tropical environment may deviate from world averages based on local ecology.

The late professor Charles Michener (WestEberhard and Engel 2017) reached the above conclusion - that wood nesting bees have a greater chance of crossing water-based on his insights into the natural history of bees. Here, we document and for the first time quantify his hypothesis, while speculating which other bee related island rules applies. In terms of body size, a well-known and described phenomenon within island ecology are the concepts of vertebrate gigantism and dwarfism, the island rule, where island migrated species over time evolve to express a larger or smaller body size (Whittaker et al., 2007; Losos and Ricklefs, 2009). Identifying if bee species express size deviations on islands could provide insights into optimal size, and thereby demonstrate if bees on the mainland are under differential resource restriction or not (Lomolino, 2005). Body size could also be studied in relation to other factors, including climate and temperature, as some species express body size variation, depending on the environmental temperature (Jones et al., 2005; Radmacher and Strohm, 2010). Furthermore, by studying the different nesting strategies, along with body sizes, the migratory capability of specific biological traits in certain habitats could be established. By identifying which biological traits are better adapted for certain conditions, adaption to climate change and potential for becoming invasive can also be established and used in conservation management (Cane, 2003; Liu and Pemberton, 2009; Morales et al., 2013; Graham et al., 2019).

A few points of improvements to the study that we were unable to incorporate follows here:

(1) Ideally, species-specific biological data should have been used, rather than having supraspecific data as a proxy for the specieslevel data. However, most species have not been studied to an extent where such data is available, and this would require extensive novel field collecting and nest location for many species where this is unknown: (2) for a possible more accurate representation of self-immigrated island species, it would be necessary to identify and exclude all human-assisted immigrants, or at least those that have actively been translocated, from the analysis; (3) for the geographical comparisons of body sizes and nesting strategy, island faunas were compared to the distribution across all species. That is, islands were compared to a mainland area equivalent of the rest of the world. Ideally, the bee faunas should be compared to the combined fauna of the mainland area used for species comparison (Table III), as these areas are the one making up the specific island's fauna. Due to complexity of the mainland fauna, we were unable to assess or delimit a comparative local fauna, and our standardized approach was to compare the global average to each island. (4) Past geological history, including changes in the sea level and former land bridges, should together with timecalibrated phylogeny be included in a solid model of isolation by distance model. (5) We did not take into account diet specialization of the bees. Diet diversity provides a limitation for specialist bees, as their food plants will not necessarily be available. However, it has been demonstrated that specialization is a labile trait (Larkin et al., 2008) and even oligolectic specialist species can switch to a broader or a different diet (Sipes and Tepedino, 2005; Sedivy et al., 2008; Rasmussen et al., 2020).

\section{ACKNOWLEDGMENTS}

Support for the data compilation of Danish bees was provided by the 15. Juni Fonden to CR. The manuscript received important and helpful reviews from two evaluators, to whom we are most grateful.

Contributions NRP and CR conceived research, NRP and $\mathrm{CR}$ compiled data, NRP ran the analysis and wrote the first draft, NRP and CR completed manuscript.

General summary

Bees usually nest in excavated ground burrows or in hollow tree cavities, with some bees having more specialized 
Table III. Areas used for comparison of source species for each of the islands studied. For each geographical region mentioned, the countries that have been combined to form this region is written in the following parentheses

\begin{tabular}{ll}
\hline Location & Areas used for comparison \\
\hline Anholt & Denmark, Sweden \\
Canary Islands & Iberian Peninsula (Spain, Portugal, and Andorra), North-West Africa \\
& (Morocco, Algeria, West Sahara, and Mauritania), rest of \\
& Macaronesia (Azores, Madeira, and Cape Verde) \\
Fiji Islands & Australia and New Zealand, Papua New Guinea, other Pacific Islands \\
& (Indonesia, Solomon Islands, Vanuatu, Tonga, and Samoa) \\
Hawaiian Islands & North America (USA, Cuba, and Dominican Republic), Asia (India, Sri \\
& Lanka, and Malaysia), other Pacific Islands (Philippines, Marshall Island, \\
& Guam, Yap Island, Mariana Islands, French Polynesia, Tonga, Cook \\
Madeira & Islands, Fiji Islands, Solomon Islands, and Galapagos Islands) \\
& Iberian Peninsula (Spain, Portugal, and Andorra), North-West Africa \\
(Morocco, Algeria, West Sahara, and Mauritania), rest of Macaronesia & (Azores, Canary Islands, and Cape Verde). \\
Malta & Northern Africa (Algeria, Tunisia, and Libya), Southern Europe (Spain, \\
Sri Lanka & Italy, Macedonia, Greece, and France) \\
& India and Southeast Asia (Thailand, Vietnam and Indonesia), Eastern Africa \\
& (Eritrea, Tanzania, Lesotho, and South Africa) and Indian Ocean (Maldives), \\
& Japan and Taiwan \\
\hline
\end{tabular}

nesting strategies, e.g., nesting in snail shells. In terms of sociality the majority of bee species, $>85 \%$, does not live in larger groups like the honey bee, but live solitarily. For bees to reach isolated islands, they need to be able to cross large water barriers. However, functional traits such as nesting behavior, flight range, and body size can limit their dispersal. In this study, the bee faunas of seven different islands or island groups (Anholt, Canary Islands, Fiji Islands, Hawaiian Islands, Madeira, Malta, and Sri Lanka) were analyzed by comparing them to the bee fauna of the closest mainland. Nesting strategy and body size for each species were recorded. The relative distribution of traits among the island species were then compared to traits of the mainland species. The mainland distribution of the two different nesting strategies demonstrated that $64.18 \%$ of all bee species can make use of a ground nesting strategy, while $32.41 \%$ are able to nest in wood. Deviation from the ground nesting strategy among the immigrated island species shows that $75.37 \%$ (Figure 1) of the variance in the deviation can be explained by distance to the closest mainland. The regression model for the deviation of wood species showed that $86.46 \%$ (Figure 2) of the variance for this type of nesting strategy can be explained via a linear model. This supports the hypothesis that wood nesting bees are more capable of island dispersal, most likely due to the associated rafting ability or the ease of being passively transported over water. The body size among the immigrated island species were shown to be commonly of moderate size, while a majority of mainland species were of small size, indicating that moderate sized bees - with longer flight range - were the more likely island migrators. The methods used could be useful for future studies of ecological influences on body size, as well as how other biological traits are adapted for migrant conditions, potentially serving as predictors in regards to climate change, dispersal ability, and control of invasive species.

Les abeilles des îles: Les abeilles qui nichent dans le bois ont-elles une meilleure capacité de dispersion?

Biogéographie des îles / Dispersion des insectes / rafting / Hymenoptera / Apidae.

Inselbienen: Haben holznistende Bienen eine grössere Fähigkeit der Verbreitung?

Inselbiogeographie / Insektenverbreitung / Rafting / Hymenoptera / Apidae.

\section{REFERENCES}

Ascher J.S., J. Pickering. (2019) Discover Life bee species guide and world checklist (Hymenoptera: Apoidea: 
Anthophila) [online] https:/www.discoverlife.org/20 /q? search=Apoidea (accessed on 15 March 2020).

Ashmole N.P., M.J. Ashmole. (1988) Insect Dispersal on Tenerife, Canary Islands: high altitude fallout and seaward drift. Arctic and Alpine Research 20, 1-12.

Balzan M.V., P. Rasmont, M. Kuhlmann, H. Dathe, A. Pauly, et al. (2016) The bees (Hymenoptera: Apoidea) of the Maltese Islands. Zootaxa 4162, 225-244.

Batra S.W. (1984) Solitary bees. Scientific American 250 , $120-127$.

Cane J.H. (2003) Exotic non-social bees (Hymenoptera: Apoidea) in North America: ecological implications, in: Strickler K.L. and Cane J.H. (Eds.), For Non-Native Crops, Whence Pollinators of the Future?, Thomas Say Publications, Entomological Society of America, Lanham, Maryland, pp. 113-126.

Cane J.H., J.L. Neff. (2011) Predicted fates of groundnesting bees in soil heated by wildfire: thermal tolerances of life stages and a survey of nesting depths. Biological Conservation 144, 2631-2636.

Cardinal S., B.N. Danforth. (2013) Bees diversified in the age of eudicots. Proceedings of the Royal Society B: Biological Sciences 280, 20122686.

da Silva C.R.B., S.V.C. Groom, M.I. Stevens, M.P. Schwarz. (2016) Current status of the introduced allodapine bee Braunsapis puangensis (Hymenoptera: Apidae) in Fiji. Austral Entomol. 55, 43-48.

Daly H.V., K.N. Magnacca. (2003) Hawaiian Hylaeus (Nesoprosopis) bees (Hymenoptera: Apoidea). University of Hawaii Press, Honolulu.

Danforth B.N., Cardinal, S., Praz C., Almeida, E.A.B, Michez, D. (2013) The impact of molecular data on our understanding of bee phylogeny and evolution. 58, 57-78.

Danforth B.N., R.L. Minckley, J.L. Neff. (2019) The Solitary Bees: Biology, Evolution, Conservation. Princeton University Press, Princeton

Danforth B.N., G.O. Poinar. (2011) Morphology, classification, and antiquity of Melittosphex burmensis (Apoidea: Melittosphecidae) and implications for early bee evolution. Journal of Paleontology 85, 882-891.

Danforth B.N., S. Sipes, J. Fang, S.G. Brady. (2006) The history of early bee diversification based on five genes plus morphology. Proceedings of the National Academy of Sciences $\mathbf{1 0 3}, 15118$.

Davies O.K., S.V.C. Groom, H.T. Ngo, M.I. Stevens, M.P. Schwarz. (2013) Diversity and origins of fijian leafcutter bees (Megachilidae). Pac. Sci. 67, 561-570.

Dressler R.L. (1982) Biology of the orchid bees (Euglossini). Annual Review of Ecology and Systematics 13 : 373-394.

Fellendorf M., C. Mohra, S. P. M. Roberts, P. Wirtz, G. Van der Zanden. (1999) The bees of Madeira (Hymenoptera, Apoidea). Bocagiana (Madeira) 197, 1-17

Gillespie R.G., D.A. Clague. (2009) Encyclopedia of Islands. University of California Press.
Graham K.K., K. Eaton, I. Obrien, P.T. Starks. (2019) Anthidium manicatum, an invasive bee, excludes a native bumble bee, Bombus impatiens, from floral resources. Biological Invasions 21, 1089-1099.

Groom S.V.C., M.I. Stevens, M.P. Schwarz. (2013) Diversification of Fijian halictine bees: insights into a recent island radiation. Mol. Phylogenet. Evol. 68, 582-594.

Hohmann H., F. La Roche, G. Ortega, J. Barquin. (1993) Bees, wasps and ants of the Canary Islands (Insecta: Hymenoptera: Aculeata). Volumes 1 and 2. ÜberseeMuseum, Bremen.

Holzapfel E.P., J.C. Harrell. (1968) Transoceanic dispersal studies of insects. Pacific Insects 10, 115-153.

iNaturalist.org. (2019) iNaturalist Research-grade Observations.

Inoka W.A., I. Karunaratne, J. Edirisinghe. (2008) Key to the identification of common bees of Sri Lanka. Journal of the National Science Foundation of Sri Lanka 36, 69-89.

Inoue K., M. Maki, M. Masuda. (1996) Evolution of Campanula flowers in relation to insect pollinators on islands, in: Lloyd D.G. and Barrett S.C.H. (Eds.), Floral Biology: Studies on Floral Evolution in Animal-Pollinated Plants, Springer US, Boston, pp. $377-400$.

Janzen D.H. (1971) Euglossine bees as long-distance pollinators of tropical plants. Science 171 (3967), 203.

Jensen J.-K., H.B. Madsen. (2018) Opdatering af humlebiernes udbredelse på Færøerne (Hymenoptera, Apoidea, Apiformes). Entomologiske Meddelelser 86, 51-56.

Jones J.C., P. Helliwell, M. Beekman, R. Maleszka, B.P. Oldroyd. (2005) The effects of rearing temperature on developmental stability and learning and memory in the honey bee, Apis mellifera. Journal of Comparative Physiology A 191, 1121-1129.

Kratochwil A., A. Schwabe. (2018) Wild bees (Anthophila) of Macaronesia - biogeographical and evolutionary aspects. Berichte der Reinhold-Tüxen-Gesellschaft 30, 149-162

Larkin L.L., J.L. Neff, B.B. Simpson. (2008) The evolution of a pollen diet: host choice and diet breadth of Andrena bees (Hymenoptera: Andrenidae). Apidologie 39, 133-145.

Liu H., R.W. Pemberton. (2009) Solitary invasive orchid bee outperforms co-occurring native bees to promote fruit set of an invasive Solanum. Oecologia 159, 515525 .

Lomolino M.V. (2005) Body size evolution in insular vertebrates: generality of the island rule. Journal of Biogeography 32, 1683-1699.

Losos J.B., R.E. Ricklefs. (2009) The Theory of Island Biogeography Revisited. Princeton University Press, Princeton

MacArthur R.H., E.O. Wilson. (1967) The Theory of Island Biogeography. Princeton University Press, Princeton. 
Madsen H.B., H.T. Schmidt, C. Rasmussen. (2015) Distriktskatalog over Danmarks bier (Hymenoptera, Apoidea). Entomologiske Meddelelser 83, 43-70.

Magnacca K.N., B. N. Danforth. (2006) Evolution and biogeography of native Hawaiian Hylaeus bees (Hymenoptera: Colletidae). Cladistics 22, 393-411.

Main D. (2019) World's largest bee, once presumed extinct, filmed alive in the wild, National Geographic. [online] https://www.nationalgeographic. com/animals/2019/02/worlds-largest-beerediscovered-not-extinct/ (accessed on 4 April 2020).

Messer A.C. (1984) Chalicodoma pluto: The world's largest bee rediscovered living communally in termite nests (Hymenoptera: Megachilidae). Journal of the Kansas Entomological Society 57, 165-168.

Michener C.D. (1964) Evolution of the nests of bees. American Zoologist 4, 227-239.

Michener C.D. (1979) Biogeography of the bees. Annals of the Missouri Botanical Garden 66, 277-347.

Michener C.D. (2007) The bees of the world, 2nd. Johns Hopkins University Press, Baltimore.

Michener C.D., R.J. McGinley, B.N. Danforth. (1994) The Bee Genera of North and Central America (Hymenoptera: Apoidea). Smithsonian Institution Press, Washington.

Morales C.L., M.P. Arbetman, S.A. Cameron, M.A. Aizen. (2013) Rapid ecological replacement of a native bumble bee by invasive species. Frontiers in Ecology and the Environment 11, 529-534.

Müller A., C. Praz, A. Dorchin. (2018) Biology of Palaearctic Wainia bees of the subgenus Caposmia including a short review on snail shell nesting in osmiine bees (Hymenoptera, Megachilidae). Journal of Hymenoptera Research 65, 61-89.

Ollerton J., R. Winfree, S. Tarrant. (2011) How many flowering plants are pollinated by animals? Oikos 120, 321-326.

Peck S.B. (1994) Aerial dispersal of insects between and to islands in the Galápagos Archipelago, Ecuador. Annals of the Entomological Society of America 87, 218224.

Radmacher S., E. Strohm. (2010) Factors affecting offspring body size in the solitary bee Osmia bicornis (Hymenoptera, Megachilidae). Apidologie 41, 169177.

Rasmussen C., A.L. Carrion, R. Castro-Urgal, S. Chamorro, V.H. Gonzalez, et al. (2012) Megachile timberlakei Cockerell (Hymenoptera: Megachilidae): Yet another adventive bee species to the Galapagos Archipelago. Pan-Pacific Entomol. 88, 98-102.

Rasmussen C., M.S. Engel, N.J. Vereecken. (2020) A primer of host-plant specialization in bees. Emerging Topics in Life Sciences: https://doi.org/10.1042 /etls20190118.

Rasmussen C., E. Sánchez, C. Skov. (2015) Description of a nest of Euglossa heterosticta from Peru, with taxonomic notes (Hymenoptera: Apidae). Journal of Melittology 55, 1-8.
Rasmussen C., H.T. Schmidt, H.B. Madsen. (2016) Distribution, phenology and host plants of Danish bees (Hymenoptera, Apoidea). Zootaxa 4212, 1-100.

Roubik D.W., S.F. Sakagami, I. Kudo. (1985) A note on distribution and nesting of the himalayan honey bee Apis laboriosa Smith (Hymenoptera: Apidae). Journal of the Kansas Entomological Society 58, 746-749.

Sammataro D., A. Avitabile. (1998) The Beekeeper's Handbook. Comstock Pub. Associates.

Sedivy C., C.J. Praz, A. Müller, A. Widmer, S. Dorn. (2008) Patterns of host-plant choice in bees of the genus Chelostoma: the constraint hypothesis of hostrange evolution in bees. Evolution 62, 2487-2507.

Sheffield C.S., S. Dumesh, M. Cheryomina. (2011) Hylaeus punctatus (Hymenoptera: Colletidae), a bee species new to Canada, with notes on other non-native species. Journal of the Entomological Society of Ontario 142, 29-43.

Sipes S.D., V.J. Tepedino. (2005) Pollen-host specificity and evolutionary patterns of host switching in a clade of specialist bees (Apoidea: Diadasia). Biological Journal of the Linnean Society 86, 487-505.

Smit J. (2007) New wasps and bees for the fauna of the Canary Islands (Hymenoptera, Aculeata). Linzer biologische Beiträge 39, 651-656.

Snelling R.R. (2003) Bees of the Hawaiian Islands, exclusive of Hylaeus (Nesoprosopis) (Hymenoptera: Apoidea). Journal of the Kansas Entomological Society $\mathbf{7 6}, 342-356$.

Vargas P., B. Rumeu, R.H. Heleno, A. Traveset, M. Nogales. (2015) Historical isolation of the Galapagos carpenter bee (Xylocopa darwini $)$ despite strong flight capability and ecological amplitude. PLoS One 10, 13.

Wcislo D.O., G. Vargas, K.E. Ihle, W.T. Wcislo. (2012) Nest construction behavior by the orchid bee Euglossa hyacinthina. J. Hymenopt. Res. 29, 15-20.

West-Eberhard M.J., M.S. Engel. (2017) Charles D. Michener. Biographical Memoirs of the National Acadamy of Sciences 2017, 1-23.

Whittaker R.J., S.G.R.J. Whittaker, J.M. FernandezPalacios. (2007) Island Biogeography: Ecology, Evolution, and Conservation. OUP Oxford, Oxford

Wijesekara A. (2001) An Annotated List of Bees (Hymenoptera: Apoidea: Apiformis) of Sri Lanka. Tijdschrift voor Entomologie 144, 145-158.

Wikelski M., J. Moxley, A. Eaton-Mordas, M.M. LópezUribe, R. Holland, et al. (2010) Large-range movements of Neotropical orchid bees observed via radio telemetry. PLoS One 5, e10738.

Williams P.H., M.V. Berezin, S.G. Cannings, B. Cederberg, F. Ødegaard, et al. (2019) The arctic and alpine bumblebees of the subgenus Alpinobombus revised from integrative assessment of species' gene coalescents and morphology (Hymenoptera, Apidae, Bombus ). Zootaxa 4625, 1-68.

Winston M.L., J.A. Dropkin, O.R. Taylor. (1981) Demography and life history characteristics of two honey bee races (Apis mellifera). Oecologia 48, 407-413. 
Zurbuchen A., L. Landert, J. Klaiber, A. Müller, S. Hein, et al. (2010) Maximum foraging ranges in solitary bees: only few individuals have the capability to cover long foraging distances. Biological Conservation 143 , 669-676.
Publisher's note Springer Nature remains neutral with regard to jurisdictional claims in published maps and institutional affiliations. 